Correspondence-Prof. J. F. Blake-C. D. Sherborn. 287

distribution of the Lamellibranchia: 29 species are recognized, six being new. The genera represented are: Leda, Nucula, Arca, Limopsis, Modiola, Inoceramus, Ostrea, Chlamys, Lima, Spondylus, Plicatula, Cardium, Cardita, Arctica, Trapezium, Corbis ?, Martesia?, and Cuspidaria.

In the concluding part the author compares the fauna of the Reussianum-zone (Chalk Rock) in England with that of other European areas, particularly N.W. Germany and Saxony. In the latter country the number of species in some groups-especially Gasteropoda and Lamellibranchia-is much greater than in England; this difference is probably due to the sea having been of less depth than in the English area. It is noticed that the species of Cephalopoda have a much wider geographical range than the other groups of the Mollusca.

Finally, by a study of the present distribution of those generawhich form the predominating element in the fauna-taken in conjunction with the other characters of the zone, the author arrives at the conclusion that in England the Reussianum-zone was probably formed between the depths of 100 and 500 fathoms.

\title{
CORRESPONDEINOE.
}

\section{ACANTHONAUTILUS BISPINOSUS.}

SIR,-Mr. Foord will find the first cousin, if not the brother, of his Acanthonautilus bispinosus" figured in "Matériaux pour la Palæontologie Russe," Tom. i, 1869, in Tab. v of a paper by Golowkinsky on the Permian formation of the central part of the Kama-Volga basin. It is there called Nautilus cornutus.

Geological Society, Buhlington House, W.

J. F. Blake. April 12, 1897.

\section{ACANTHONAUTILUS: A CORRECTION.}

Sir,-In the April number of the Geological Magazine appears a description of Acanthonautilus as a new genus. As this has already been published in Dr. Foord's Inaugural Dissertation (München, in 1896), "Ueber die Orthoceren des Kohlenkalks [Carboniferous Limestone] von Irland, etc.," the statement that it is new is likely to mislead the student.

540, Kive's Road, Loxpon, S.W. April 26, 1897 .

Sir,-Since my paper on Acanthonautilus bispinosus appeared in your April number, my attention has been directed to a work in the Russian language ("Material for the Geology of Russia," vol. i, 1869), containing a paper by N. Golovkinsky, in which is figured and described a species-Nautilus cornutus-closely related to mine, though from a higher horizon, the Permian. From a study of the figures it is clear that the species are quite distinct. Thus, in $\boldsymbol{A}$. bispinosus the shell expands rapidly, and has a broad and shallow

\footnotetext{
1 Geol. MAa., April, 1897, p. 147, Pl. VI.
} 
hyponomic sinus; the spines (similar in structure in the two species) are nearly straight, and slightly inclined downwards. The septa are not numerous. In the Russian species, on the other hand, the shell is more slowly expanding, the hyponomic sinus small and inconspicuous, the spines slightly curved, and inclined upwards. The septa, only faintly indicated on the larger of the two specimens figured, are more numerous than in the Irish species. The siphuncle, not seen in $A$. bispinosus, is in $N$. cornutus sub. central, and inclined towards the inner margin of the shell; this is the case at least in the smaller of the specimens figured, which also shows in a section the slow expansion of the whorls.

The discovery of the Irish Carboniferous species shows that this peculiar type of Nautiloid had a wide geographical range, while its appearance in the Permian of Russia extends its range in time.

The work in which $N$. cornutus is described seems to have been generally overlooked, as I have seen no reference to it even in books and papers dealing exclusively with Carboniferous or PermoCarboniferous fossils.

My thanks are due to you, Sir, for your courtesy in allowing me to see Professor Blake's letter, thus enabling me to compare and comment upon the two species; and to Professor Blake science is indebted for having drawn attention to this "first cousin" of A. bispinosus. Arthur H. Foord.

Dublin, May 13, 1897.

P.S.-With reference to Mr. Sherborn's letter which you have also kindly granted me the privilege of perusing, I can only say that I did not consider that the private distribution of a few copies of a paper could fairly constitute publication. The fact, however, seems to be that when once a paper has left its author's hands, and can therefore be quoted, it must be considered as published. I am obliged to Mr. Sherborn for pointing this out to me; I could have no better authority to guide me in the matter than his.-A. H. F.

\section{MISCEIIANEOUS.}

"The Distribution of Drift in Ireland in its relation to Agriculture" is the title of a paper by Mr. J. R. Kilroe (Proc. Royal Dublin Soc., sor. 2, vol. viii, 1897, pp. 421-431: published separately, price 6d.). It is accompanied by a geological map, printed in colours to show the areas where the more solid rocks appear at the surface, the large tracts (two-thirds or more of the country) which are covered by various drift deposits being left blank. As the author rightly points out, a map that would meet the requirements of the agriculturist must show, on a fairly large scale, the distribution of the subsoils, and indicate not only the materials of which they are composed, but their thicknesses at different localities, and in some cases the subjacent strata. This could be indicated by colours, letters, and numbers ; and the author's aim is to make suggestions towards this object. He appends a table showing the nature of soils, subsoils, and boulder-clays in various parts of Ireland. 